\title{
PEDIATRICS
}

\section{Immunologic and Clinical Responses to Rituximab in a Child With Opsoclonus-Myoclonus Syndrome}

Michael R. Pranzatelli, Elizabeth D. Tate, Anna L. Travelstead and Darryl Longee

Pediatrics 2005;115;115-119; originally published online Dec 15, 2004;

DOI: $10.1542 /$ peds.2004-0845

\section{This information is current as of January 5, 2005}

The online version of this article, along with updated information and services, is located on the World Wide Web at:

http://www.pediatrics.org/cgi/content/full/115/1/e115

PEDIATRICS is the official journal of the American Academy of Pediatrics. A monthly publication, it has been published continuously since 1948. PEDIATRICS is owned, published, and trademarked by the American Academy of Pediatrics, 141 Northwest Point Boulevard, Elk Grove Village, Illinois, 60007. Copyright @ 2004 by the American Academy of Pediatrics. All rights reserved. Print ISSN: 0031-4005. Online ISSN: 1098-4275.

\section{American Academy of Pediatrics}




\title{
Immunologic and Clinical Responses to Rituximab in a Child With Opsoclonus-Myoclonus Syndrome
}

\author{
Michael R. Pranzatelli, MD*ł; Elizabeth D. Tate, FNP-C, MN*; Anna L. Travelstead, BS, MT(ASCP)§; \\ and Darryl Longee, MD\|
}

\begin{abstract}
Opsoclonus-myoclonus syndrome (OMS) is an autoimmune disorder with serious neurodevelopmental morbidity and limited treatment options. We treated a toddler with moderately severe OMS with rituximab, a monoclonal anti-B cell antibody. The patient's clinical response was documented on videotape and scored with the OMS Evaluation Scale. Cerebrospinal fluid lymphocyte subsets were evaluated by flow-cytometric immunophenotyping, with a comprehensive panel of monoclonal antibodies. Eradication of cerebrospinal fluid B cells, which previously were expanded, was associated with dramatic clinical improvement. There also were secondary changes in other lymphocyte subsets that might be relevant to the clinical response and lack of serious infections. In addition to clarifying the immune response to $B$-cell depletion, these data reveal a promising new therapy for OMS that warrants a phase I clinical trial. Pediatrics 2005;115:e115-e119. URL: www.pediatrics.org/cgi/doi/10.1542/peds.2004-0845; neuroblastoma, Kinsbourne syndrome, dancing eyes syndrome, paraneoplastic disorder, cerebrospinal fluid lymphocyte immunophenotyping.
\end{abstract}

ABBREVIATIONS. OMS, opsoclonus-myoclonus syndrome; CSF, cerebrospinal fluid; NK, natural killer; IVIg, intravenously administered immunoglobulin; Ig, immunoglobulin.

$\mathrm{R}$ ituximab (Rituxan), a monoclonal antibody directed against $B$ cells, binds to the CD20 antigen on the surface of mature B cells, which it targets for apoptosis and immune system-mediated destruction. ${ }^{1}$ Rituximab was approved by the US Food and Drug Administration in 1997 to treat B-cell non-Hodgkin's lymphomas ${ }^{2}$ but has been used offlabel for the treatment of several types of autoimmune disorders among children and adults, such as autoimmune hemolytic anemia, ${ }^{3}$ idiopathic autoimmune thrombocytopenia, ${ }^{4}$ rheumatoid arthritis, ${ }^{5}$ lupus, $^{6}$ autoimmune neuropathy, ${ }^{7}$ and Wegener's granulomatosis. ${ }^{8}$

Rituximab seems ideal for the study and treatment

From the Departments of *Neurology, †Pediatrics, and §Medical Microbiology and Immunology, Southern Illinois University School of Medicine, Springfield, Illinois; and ||Department of Pediatric Hematology/Oncology, Carilion Roanoke Community Hospital, Roanoke, Virginia.

Accepted for publication Aug 16, 2004.

doi:10.1542/peds.2004-0845

No conflict of interest declared.

Reprint requests to (M.R.P.) National Pediatric Myoclonus Center, Southern Illinois University School of Medicine, PO Box 19643, Springfield, IL 627949643. E-mail: pranzatelli@siumed.edu

PEDIATRICS (ISSN 0031 4005). Copyright @ 2005 by the American Academy of Pediatrics. of childhood opsoclonus-myoclonus syndrome (OMS), a serious neurologic disorder in need of more effective therapy. ${ }^{9}$ OMS is purported to be humorally mediated, and antibodies to diverse autoantigens have been described. ${ }^{10,11}$ Removal of autoantibodies through plasmapheresis at the toddler stage, when OMS usually develops, is not feasible technically. If pathogenic B-cell perpetrators could be removed, however, then perhaps the same result could be achieved. Also, B cells can function as antigenpresenting cells to T cells, ${ }^{12}$ and their removal might thus be strategic. Recently, we demonstrated an increased percentage of $\mathrm{B}$ cells in the cerebrospinal fluid (CSF) of children with OMS, and CSF B-cell expansion proved to be a reliable biomarker of disease activity. ${ }^{13}$ We also found that rituximab, when added to conventional immunotherapy for 6 children with OMS, reduced the number of $B$ cells in the CSF, with clinical improvement. ${ }^{14}$

We evaluated a child with moderately severe OMS for whom the percentage of B cells in the CSF was elevated. In consideration of the use of rituximab as monotherapy, there were several unknown factors. Would therapy result in sufficient clinical improvement? Would it still remove CSF B cells and, if so, would there be compensatory changes in other CSF lymphocyte subsets? Here we report on the clinical and immunologic effects of rituximab for that child.

\section{CASE REPORT}

When first evaluated at the National Pediatric Myoclonus Center, the child was 30 months of age. She was healthy until the age of 24 months, when she experienced various respiratory infections, including otitis media, bronchitis, and pneumonia, which were treated with azithromycin and erythromycin. Then the patient began to stumble and display balance problems and irritability. Soon she lost her ability to feed, sit, or walk. Muscle jerks were evident during sleep, and the patient slept for only short periods. She experienced rage attacks 4 or 5 times each day.

Several weeks later, after the appearance of trembling and jerking eyes, a diagnosis of OMS was made. Head magnetic resonance imaging and electroencephalographic findings were normal. The serum neuron-specific enolase concentration was mildly elevated at $11.1 \mu \mathrm{g} / \mathrm{L}$ (normal: 3.7-8.9 $\mu \mathrm{g} / \mathrm{L}$ ), but a search for a neuroblastoma through magnetic resonance imaging of the chest, abdomen, and pelvis and urine catecholamine screening yielded negative results.

At 25 months of age, the patient was treated with intravenously administered immunoglobulin (IVIg) $(1 \mathrm{~g} / \mathrm{kg})$ for each of 2 consecutive days. The mother reported that the patient responded to the treatment but it was not continued. Later, oral prednisone treatment was attempted, but the child refused the medication regardless of how it was presented. No other therapy was administered.

In the subsequent months, the patient exhibited staring epi- 
sodes not associated with convulsive movements and she drooled. Her behavior remained problematic, although she no longer experienced rage attacks. She still did not speak in sentences, and she was unable to run. Her jerkiness was worse when she attempted to move and during illnesses. She was unusually sensitive to bright lights.

The developmental history before the onset of OMS was unremarkable. The patient sat at 6 to 7 months of age, crawled at 5 to 6 months, rolled over at 3 months, stood independently at 9 months, walked at 9 months, ran at 18 months, and was beginning to speak in sentences at 24 months. She was almost fully toilet trained.

In an examination, the patient's head circumference $(49.2 \mathrm{~cm}$, 60th percentile), weight $(12.7 \mathrm{~kg}$, 25 th percentile), and height (36 inches, 30th percentile) were age-appropriate. Her vital signs were unremarkable. The patient was an extremely shy little girl with obvious neurologic abnormalities. She appeared to see and hear well, but she was not socially appropriate and spoke only a few single words, such as "no" and "mama," and her few attempts to form a 2-word phrase could not be understood. Opsoclonus, strabismus, and sialorrhea without other cranial nerve abnormalities were observed. The child exhibited opsoclonus and distal upperextremity myoclonus, as well as ataxia. Her ability to perform fine-motor tasks was less impaired than was her gait, which was severely abnormal. She could pull herself to a standing position from a sitting position on the floor; however, she could not take steps independently. When continuously held by the arms in a standing position, she stood on her toes and took a few staggering steps. Her base was quite wide. Deep tendon reflexes were normal, and no clonus or pathologic reflexes were noted. Muscle strength and tone were normal.

The child was in need of immunotherapy, but her mother preferred to avoid treatment with corticotropin, the most effective agent. Therefore, a practical alternative was needed. After considering chemotherapy with cyclophosphamide, which we have not found to be effective in achieving neurologic remission, and "steroid-sparers" such as azathioprine, which we deemed insufficient for the severity of disease, we chose rituximab. Parental consent for this institutional review board-approved immunophenotyping study was obtained.

The results of routine CSF studies were normal. The leukocyte count was 2 cells per $\mathrm{mm}^{3}$. The protein concentration was 53 $\mathrm{mg} / \mathrm{dL}$, and the glucose concentration was $25 \mathrm{mg} / \mathrm{dL}$. The electrophoretically determined protein distribution was normal. The immunoglobulin (Ig) G synthesis rate was $<0.01 \mathrm{mg}$ per 24 hours. Oligoclonal bands were not detected.

\section{METHODS}

\section{Videotape Scoring}

The child was videotaped before and after treatment. A trained observer who was blinded with respect to treatment status rated motor impairment with the OMS evaluation scale, a published 12-item scale indicating increasing neurologic severity or impairment. ${ }^{15}$ The total score was calculated as the sum of subscores, with a score of 36 indicating maximal abnormality.

\section{Flow Cytometry}

CSF and blood samples were obtained before and after treatment, as described previously. ${ }^{16}$ Flow cytometry was performed with published methods. ${ }^{16,17}$ Our data for neurologic control subjects without immunologic disorders were used for comparison. ${ }^{13,16}$ Because the relative and absolute sizes of the blood lymphocyte pool change with time, ${ }^{18}$ we referred to data for the age range most applicable to our patient. Rituximab can interfere with anti-CD20 binding; therefore, CD19 was the principal B-cell marker we used to assess the outcome.

\section{Rituximab Treatment}

Rituximab (Genentech, Inc, South San Francisco, CA; IDEC Pharmaceuticals Co, San Diego, CA; $375 \mathrm{mg} / \mathrm{m}^{2}$ ) was administered through intravenous infusion once each week for 4 consecutive weeks. The dosage was the same as the Food and Drug Administration-approved dosage for the treatment of lymphoma. ${ }^{2}$ The child was pretreated with acetaminophen and diphenhydramine.

\section{RESULTS}

\section{Clinical Response to Rituximab Monotherapy}

The earliest sign of clinical improvement occurred 1 week after the initial rituximab treatment. The child appeared less tremulous and calmer. By the fourth infusion, the consensus was that the patient was faring much better and seemed happier, "more focused," and "more stable."

Three months after completion of rituximab therapy ( 4 months after the first infusion), the patient's mother reported that the child "got her personality back." She showed improvement in multiple areas, such as better sleep, less drooling, and no rage attacks, and her "eyes were straight." The child was starting to form short sentences and followed commands, and her mother was considering a preschool for her. The physical therapist thought that the patient had made "tremendous progress physically," being able to negotiate standard stairs with one hand on the rail, to jump independently, to step over objects in her pathway, and to kick a ball forward. There had been 2 upper-respiratory tract infections, for which the child was treated with azithromycin.

In the examination video (published as supporting information on the Pediatrics Web site), the child was alert and attentive. She could reach for objects with either hand. She was able to stack vertically 2 or 3 small wooden blocks. She demonstrated intermittent right esotropia but no opsoclonus. Occasional sialorrhea was noted. The patient was able to sit without support, walk (with a tendency to be up on her toes), and run (with a wide base). Although the patient was slightly unsteady at times, she did not fall. Her speech remained limited to a few single words, and she did not separate well from her mother.

The child's motor performance on the OMS evaluation scale (Table 1) indicated improved station and gait, fewer fine-motor difficulties, and elimination of opsoclonus. The total score decreased by $42 \%$, which represented almost 1 severity category (Fig 1).

\section{B-Cell Response to Rituximab}

By 3 months after rituximab treatment, CSF CD19+ and $\mathrm{CD}^{+} \mathrm{B}$ cells were depleted (Fig 1). The CSF $\mathrm{CD}^{+}$B-cell subset was still absent at 9 months, and $\mathrm{CD}{ }^{+} \mathrm{B}$ cells had returned to approximately one third of their pretreatment value, within the normal range $(<2 \%)$. In blood, $B$ cells were depleted at 3 months. By 9 to 12 months, the percentage of B cells in peripheral blood had returned to the baseline value.

\section{Secondary Responses of Other Lymphocytes}

There were also changes in other lymphocyte subsets in CSF (Table 2). The $\mathrm{CD}^{+} \mathrm{T}$ cell/CD8 ${ }^{+} \mathrm{T}$ cell ratio, which is characteristically low in OMS, was 1.3 before rituximab treatment and 0.7 after rituximab treatment, compared with $3.8 \pm 0.7$ in control samples. Although there was an increase in the percentage of helper/inducer $\mathrm{T}$ cells, it was more than matched by an increase in the percentage of cytotoxic/suppressor $\mathrm{T}$ cells, so that the ratio did not improve. 
TABLE 1. Effects of Rituximab on Motor Performance on the OMS Evaluation Scale

\begin{tabular}{lccc}
\hline \multicolumn{1}{c}{ Scale Item } & $\begin{array}{c}\text { Before } \\
\text { Treatment }\end{array}$ & $\begin{array}{c}\text { After } \\
\text { Treatment, } \\
3 \text { mo }\end{array}$ & $\begin{array}{c}\text { After } \\
\text { Treatment, } \\
9 \text { mo }\end{array}$ \\
\hline 1. Walking, side-to-side imbalance & 3 & 2 & 0 \\
2. Walking, front-to-back imbalance & 3 & 2 & 0 \\
3. Walking, wide base & 3 & 2 & 0 \\
4. Instability while standing (feet apart) & 3 & 2 & 0 \\
5. Difficulty achieving standing position & 3 & 2 & 0 \\
6. Truncal instability while sitting & 2 & 1 & 0 \\
7. Targeting difficulty & 1 & 1 & 0 \\
8. Difficulty grasping with one hand & 0 & 0 & 0 \\
9. Difficulty with pincer grasp & 2 & 0 & 0 \\
10. Abnormal eye movements while tracking (fixation) & 0 & 0 & 0 \\
11. Abnormal eye movements while resting & 1 & 0 & 0 \\
12. Speech abnormality (dysarthria) & 3 & 2 & 2 \\
\hline
\end{tabular}

Each item was scored from videotapes, with a Likert scale of 0 to $3(0=$ normal, $1=$ mild, $2=$ moderate, 3 = severe).

CSF B-cells

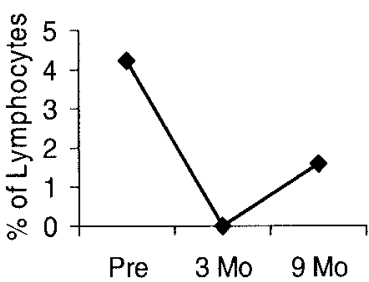

Blood B-cells

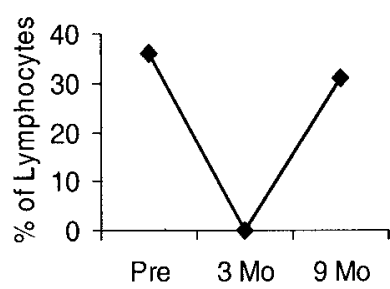

CSF CD5+ B-cells

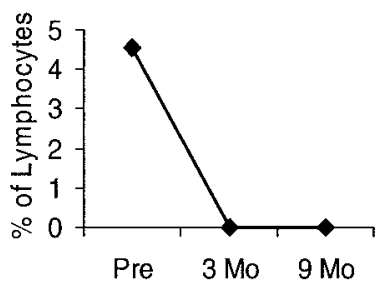

Blood CD5 $^{+}$B-cells

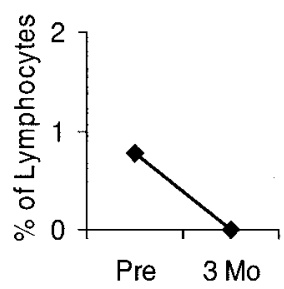

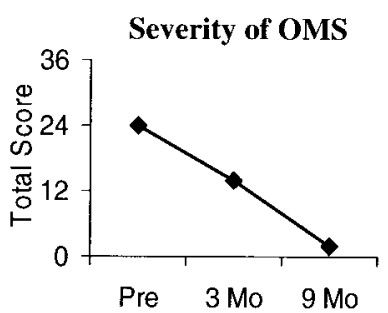

Fig 1. Effects of rituximab on CSF B cells and severity of OMS Three months after completion of rituximab infusions, CSF and blood B cells, including the $\mathrm{CD}^{+}{ }^{+}$subset, were depleted and the total score decreased from the upper limit of moderate to the upper limit of mild categories. Even at 9 months, the percentages of CSF B cells remained in the normal range when percentages in blood had normalized. For comparison, the cell percentage (mean \pm SEM) in controls $(n=18)$ was $0.85 \pm 0.20$ (range: $0-2.26)$ for $\mathrm{CD} 19^{+} \mathrm{B}$ cells and $0.23 \pm 0.13$ (range: $0-2.0$ ) for $\mathrm{CD}^{+} \mathrm{B}$ cells. Clinical severity was classified as mild if the total score was 0 to 12 , moderate if the score was 13 to 24 , and severe if the score was 25 to 36 .

The percentage of "unconventional" $(\gamma \delta)$ CSF T cells, which was fourfold above normal values initially, decreased into the control range after rituximab treatment. In contrast, there was a 1.4-fold increase in the percentage of activated $\mathrm{T}$ cells above the already elevated pretreatment percentage. The T-cell maturation status changed from a memory pheno-

type to a more naive phenotype, as exemplified by an increase in the CD45RA ${ }^{+}$cell/CD45RO ${ }^{+}$cell ratio from 0.03 to 1.1, compared with 0.46 in control samples. Changes in the percentages of natural killer (NK) and NK-like T cells were small, and percentages were close to control values both before and after treatment.

The ratio of CSF helper/inducer $\mathrm{T}$ cells that were positive for antiinflammatory/inflammatory (interleukin-4/interferon- $\gamma$ ) intracellular cytokines, which is normally $2.6 \% \pm 1.0 \%$, was $1.1 \%$ before treatment and $2.4 \%$ after treatment. Although the intracellular cytokine levels decreased after treatment, they were already low.

In blood, there were transient increases in the percentages of all cell types by 3 months after rituximab treatment (data not shown). The largest changes (4fold) were for activated $\mathrm{T}$ cells (either HLA-DR ${ }^{+}$or CD25 ${ }^{+}$) and NK cells (1.3-fold). For other cell types, the increases ranged from 32 to $59 \%$, except for NKlike T cells and $\gamma \delta \mathrm{T}$ cells, with increases of 9 to $16 \%$. At 9 and 12 months, however, the percentages had returned to pretreatment values.

Igs

There was no change in CSF IgG levels (Table 3). In serum, there was a 5\% reduction in the IgG level and a $69 \%$ decrease in the IgM level, which brought IgM levels to the lower limit of the reference range. IgA levels increased by $44 \%$ but remained well within the reference range.

\section{Subsequent Course}

At the age of 38 months, the patient continued to experience frequent persistent upper-respiratory tract illnesses, as she had before treatment. Because we thought these might be slowing her progress, we administered IVIg $(1 \mathrm{~g} / \mathrm{kg})$. The patient did not exhibit dramatic neurologic improvement after IVIg treatment, but she has not had a problem with infections.

At the age of 42 months, the patient was faring very well, climbing, jumping, walking and running; she had recently been toilet trained. Her mother denied any behavior problems except that the child was "bossy." At home, the child spoke in 4- or 5-word 


\begin{tabular}{|c|c|c|c|c|}
\hline \multirow[t]{2}{*}{ Cell Type } & \multirow[t]{2}{*}{ CD Marker } & \multicolumn{3}{|c|}{$\%$ of CSF Lymphocytes (\% Change) } \\
\hline & & $\begin{array}{l}\text { Before } \\
\text { Treatment }\end{array}$ & $\begin{array}{c}\text { After Treatment, } \\
3 \mathrm{mo}\end{array}$ & Control \\
\hline Conventional $(\alpha \beta) \mathrm{T}$ cell & $\mathrm{CD}^{+}$ & 83 & $90(+6.5)$ & $87 \pm 2.9$ \\
\hline Helper/inducer T cell & $\mathrm{CD}^{+} \mathrm{CD}^{+}{ }^{+}$ & 22 & $34(+57)$ & $62 \pm 3.8$ \\
\hline Cytotoxic/suppressor T cell & $\mathrm{CD}^{+} \mathrm{CD}^{+}$ & 16 & $47(+186)$ & $21 \pm 2.2$ \\
\hline Activated T cell & $\mathrm{CD}^{+}{ }^{\mathrm{HLA}}-\mathrm{DR}^{+}$ & 29 & $42(+44)$ & $13 \pm 1.1$ \\
\hline Activated T cell (interleukin-2 receptor) & $\mathrm{CD}^{+}{ }^{+} \mathrm{CD}_{25} 5^{+}$ & 3.2 & $2.1(-34)$ & $2.6 \pm 0.8$ \\
\hline Naïve T cell & $\mathrm{CD}^{+}{ }^{+} \mathrm{CD}_{45 \mathrm{RA}^{+}}{ }^{+}$ & 14 & $47(+227)$ & $22 \pm 4.8$ \\
\hline Memory T cell & $\mathrm{CD}^{+}{ }^{\mathrm{CD}} 45 \mathrm{RO}^{+}$ & 32 & $42(+32)$ & $47 \pm 4.4$ \\
\hline NK-like T cell & $\mathrm{CD}^{+}{ }^{\mathrm{CD}} 16 / 56^{+}$ & 2.1 & $1.4(-33)$ & $2.2 \pm 0.5$ \\
\hline NK cell & $\mathrm{CD}^{-}{ }^{-} \mathrm{CD} 16 / 56^{+}$ & 6.3 & $5.2(-17)$ & $4.6 \pm 1.0$ \\
\hline Unconventional $(\gamma \delta) \mathrm{T}$ cell & $\mathrm{T}$ cell receptor $\gamma \delta$ & 20 & $4.5(-78)$ & $4.9 \pm 1.1$ \\
\hline T-helper 1 cytokine (Th1) & Interferon- $\gamma$ & 8.2 & $0.9(-89)$ & $2.0 \pm 0.7$ \\
\hline T-helper 2 cytokine (Th2) & Interleukin-4 & 8.7 & $2.1(-76)$ & $5.1 \pm 1.6$ \\
\hline
\end{tabular}

Control values are from our published CSF data for pediatric neurologic control subjects without immunologic disorders $(n=18)$ and from unpublished cytokine data $(n=5)$. Percentage changes, compared with pretreatment values, are given in parentheses.

TABLE 3. Effects of Rituximab Monotherapy on CSF and Blood Ig Levels

\begin{tabular}{llccc}
\hline Source & Class & \multicolumn{3}{c}{$\mathrm{Ig}, \mathrm{mg} / \mathrm{dL}$} \\
\cline { 3 - 5 } & & $\begin{array}{c}\text { Before } \\
\text { Treatment }\end{array}$ & $\begin{array}{c}\text { After Treatment, } \\
3 \text { mo }\end{array}$ & $\begin{array}{c}\text { Reference } \\
\text { Range }\end{array}$ \\
\hline \multirow{2}{*}{ CSF } & IgG & 1.1 & 1.0 & $0.5-6.1$ \\
& IgM & 0.04 & 0.06 & $<0.09$ \\
Blood & IgG & 584 & 553 & $441-1135$ \\
& IgM & 156 & 49 & $47-200$ \\
& IgA & 45 & 65 & $22-159$ \\
\hline
\end{tabular}

sentences, and her mother said that $>50 \%$ of the speech would be understandable to strangers. In an examination, the child was able to pick up objects and was very steady. She stacked 7 of 7 small wooden blocks and sat without support. She walked to her mother at a normal pace, with no ataxia. All of these changes were reflected in an additional large decrease in the total score to near normal. The patient remained very shy and reluctant to speak.

At 53 months of age, ie, 18 months after rituximab treatment, the patient exhibits no motor deficits except for mild/moderate dysarthria. IVIg treatment is being gradually discontinued. No relapses have occurred.

In blood, the relative sizes of blood lymphocyte subsets reverted to pretreatment values. In CSF, the percentage of the helper/inducer T-cell pool continued to increase toward normal values, and the percentage of $\gamma \delta \mathrm{T}$ cells remained at one half the increased pretreatment value. The percentage of activated $\mathrm{T}$ cells decreased to the baseline value, which was still elevated, and the percentage of cytotoxic/suppressor $\mathrm{T}$ cells remained high. The cytokine ratio continued to favor the presumably antiinflammatory $\mathrm{T}$ helper type 2 profile.

\section{DISCUSSION}

For our patient, rituximab monotherapy was associated with marked clinical improvement without the need for corticotropin or corticosteroids, which in our experience is extraordinary. No child with disease of equal severity exhibits spontaneous improvement. ${ }^{19,20}$ Others have reported poor outcomes for moderate and severe OMS, ${ }^{21,22}$ and the relapse rate with conventional treatment is $68 \% .^{20}$ Our patient has experienced no relapses.

Striking clinical improvement was correlated with elimination of CSF B cells, which were expanded before treatment. We showed previously that B-cell expansion in OMS is a reliable biomarker of disease activity. ${ }^{13}$ This type of response supports the hypothesis that there is a humoral component to the pathophysiologic processes of OMS. ${ }^{23}$ The capacity of rituximab to destroy CSF B cells might be attributable to interruption of bidirectional B-cell trafficking 24 between the circulation and the brain. B cells might have been targeted when they egressed, or perhaps enough rituximab crossed the blood-brain barrier to kill the cells in the CSF.

The eventual return of B cells to the blood and CSF did not induce a relapse. The explanation we propose is that CSF B cells were no longer expanded, instead falling within the control range. We showed previously that blood B cell levels are not correlated with neurologic severity; therefore, a return to pretreatment levels should not matter as long as the CSF levels remain normal. It is also possible that pathogenic B-cell clones were eradicated and tolerance ensued, but this hypothesis would require a different technique for evaluation.

To our surprise, however (because no data were available previously), removal of B cells had a cascade effect on other CSF lymphocyte subsets. Most of these changes, principally T-cell responses, would be expected to be clinically favorable. We previously demonstrated that the percentage of $\gamma \delta$ T cells (unconventional T cells) in CSF is also increased in OMS, and this expansion is correlated with OMS severity. ${ }^{16}$ For our patient, the percentage of CSF $\gamma \delta \mathrm{T}$ cells decreased into the normal range after treatment with rituximab. This could have had a beneficial clinical effect if $\gamma \delta \mathrm{T}$ cells promote inflammation. ${ }^{16}$ Interpretation of the increase in cytotoxic/suppressor T cells depends on whether the cells were acting in their cytotoxic or suppressor capacity. Although the percentage of activated $T$ cells returned to pretreatment values, rituximab does not address increased T-cell activation.

In retrospect, compensatory changes in non-B- 
cell lymphocytes are probably to be expected, given the impact of removing such an important cell type. In the circulation, increases in the relative sizes of the T-cell and NK cell pools might have helped prevent the occurrence of a major infection, but serum Ig levels did not decrease into the abnormal range. These changes are unlikely to be attributable to random variation, because we noted that the immunophenotype of healthy individuals remains stable unless immunotherapy is administered. This is a case report, however, and a formal study is needed for confirmation.

Lack of serum Ig depletion is perhaps counterintuitive in the presence of B-cell elimination and suggests the argument that the clinical effect of rituximab is not humorally mediated. However, given the circulating IgM autoantibodies noted in OMS, ${ }^{25}$ it would be unwise to discount completely the decrease in serum IgM levels for this patient. IgG levels were not reduced in CSF or blood, possibly because of the longer half-life of IgG. If the clinical effect of rituximab is not antibody related, then it may be attributable to removal of $B$ cells as antigen-presenting cells. ${ }^{12}$

These data could shed light on why there was not a complete clinical response at a time when CSF B cells were depleted. Perhaps pathogenic Igs were still present in sufficient quantities or there were still B cells in the brain. Alternatively, the finding might not have anything to do with Igs or B cells, reflecting instead the T-cell component of OMS, which was untreated, or brain injury caused by delayed treatment. Presently, these are only speculations that require additional study.

IVIg might have contributed to clinical improvement in the latter part of the assessment period, when it was introduced. However, it usually does not alter the CSF immunophenotype. ${ }^{13,16}$ We do think it helped stabilize the child's condition by facilitating her recovery from various minor upperrespiratory tract illnesses. IVIg was compatible with rituximab therapy.

Clinicians need to be aware of potential problems with rituximab. It is genetically engineered from $\mathrm{mu}-$ rine cells, the proteins of which can cause hypersensitivity. ${ }^{2}$ We observed none of the possible infusionrelated symptoms, such as fever, chills, nausea, hives, fatigue, headache, or itching, probably because of our pretreatments. We also did not encounter rare but more serious hypersensitivity reactions such as hypotension, bronchospasm, or angioedema. Although very long-term data for children are lacking, B-cell recovery starts $\sim 6$ months after the completion of treatment and typically normalizes by 12 months, and serum Ig levels usually remain normal or slightly reduced. ${ }^{1}$ Immunoreactivity to rituximab is uncommon.

\section{CONCLUSIONS}

We noted a promising clinical response in OMS with a monoclonal antibody that eradicates CSF B cells. The transient secondary changes in non-B-cell CSF lymphocyte subsets are of unclear clinical sig- nificance. There is sufficient promise to warrant a phase I clinical trial of rituximab, for which a comprehensive panel of lymphocyte markers should be used.

\section{REFERENCES}

1. Cerny T, Borisch B, Introna M, Johnson P, Rose AL. Mechanism of action of rituximab. Anticancer Drugs. 2002;13(suppl 2):S3-S10

2. Grillo-López AJ, White CA, Varns C, et al. Overview of the clinical development of rituximab: first monoclonal antibody approved for the treatment of lymphoma. Semin Oncol. 1999;26(suppl 14):66-73

3. Quartier P, Brethon B, Philippet P, et al. Treatment of childhood autoimmune hemolytic anemia with rituximab. Lancet. 2001;358:1511-1513

4. Faurschou M, Hasselbalch HC, Nielsen OJ. Sustained remission of platelet counts following monoclonal anti-CD20 antibody therapy in two cases of idiopathic autoimmune thrombocytopenia and neutropenia. Eur J Haematol. 2001;66:408-411

5. Leandro MJ, Edwards JC, Cambridge G. Clinical outcome in 22 patients with rheumatoid arthritis treated with B lymphocyte depletion. Ann Rheum Dis. 2002;61:883-888

6. Anolik J, Campbell D, Felgar R, et al. The relationship of Fc $\gamma$ RIIIa genotype to degree of $B$ cell depletion by rituximab in the treatment of systemic lupus erythematosus. Arthritis Rheum. 2003;48:455-459

7. Pestronk J, Florence J, Miller T, et al. Treatment of IgM antibody associated polyneuropathies using rituximab. Neurol Neurosurg Psychiatry. 2003;74:485-489

8. Specks U, Fervenza FC, McDonald TJ, Hogan MC. Response of Wegener's granulomatosis to anti-CD20 chimeric monoclonal antibody therapy. Arthritis Rheum. 2001;44:2836-2840

9. Kinsbourne M. Myoclonic encephalopathy of infants. J Neurol Neurosurg Psychiatry. 1962;25:221-276

10. Antunes NL, KhakooY, Mattay KK, et al. Antineuronal antibodies in patients with neuroblastoma and paraneoplastic opsoclonus-myoclonus. J Pediatr Hematol Oncol. 2000;22:315-320

11. Bataller L, Rosenfeld MR, Graus F, et al. Autoantigen diversity in the opsoclonus-myoclonus syndrome. Ann Neurol. 2003;53:347-353

12. Chung JB, Wells AD, Adler S, et al. Incomplete activation of CD4 T cells by antigen-presenting transitional immature B cells: implications for peripheral B and T cell responsiveness. J Immunol. 2003;171:1758-1767

13. Pranzatelli MR, Travelstead AL, Tate ED, Allison TJ, Verhulst SJ. CSF B-cell expansion in opsoclonus-myoclonus syndrome: a biomarker of disease activity. Mov Disord. 2004;19:770-777

14. Pranzatelli MR, Tate ED, Travelstead AL, Verhulst SJ. CSF B-cell expansion in opsoclonus-myoclonus: effect of rituximab, an anti-B-cell monoclonal antibody. Neurology. 2003;60(suppl 1):A395

15. Pranzatelli MR, Tate ED, Galvan I, Wheeler A. A controlled pilot study of piracetam for pediatric opsoclonus-myoclonus. Clin Neuropharmacol. 2001;24:352-357

16. Pranzatelli MR, Travelstead AL, Tate ED, et al. B- and T-cell markers in opsoclonus-myoclonus syndrome: immunophenotyping of CSF lymphocytes. Neurology. 2004;62:1526-1532

17. Svenningsson A, Anderson O, Edsbagge M, et al. Lymphocyte phenotype and subset distribution in normal cerebrospinal fluid. J Neuroimmunol. 1995;63:39-46

18. Comans-Bitter WM, De Groot R, Van den Beemd R, et al. Immunophenotyping of blood lymphocytes in childhood: reference values for lymphocyte subpopulations. J Pediatr. 1997;130:388-393

19. Hammer MS, Larsen MB, Stack CV. Outcome of children with opsoclonus-myoclonus regardless of etiology. Pediatr Neurol. 1995;13: 21-24

20. Pranzatelli MR, Tate ED, Wheeler A. Screening for autoantibodies in children with opsoclonus-myoclonus-ataxia. Pediatr Neurol. 2002;27: 384-387

21. Papero PH, Pranzatelli MR, Margolis JL, et al. Neurobehavioral and psychosocial functioning of children with opsoclonus-myoclonus syndrome. Dev Med Child Neurol. 1995;37:915-932

22. Pohl KRE, Pritchard J, Wilson J. Neurological sequelae of the dancing eye syndrome. Eur J Pediatr. 1996;155:237-244

23. Pranzatelli MR. The immunopharmacology of the opsoclonusmyoclonus syndrome. Clin Neuropharmacol. 1996;19:1-47

24. Hickey WF. Leukocyte traffic in the central nervous system: the participants and their roles. Semin Immunol. 1999;11:125-137

25. Connolly AM, Pestronk A, Shobhna M, et al. Serum autoantibodies in childhood opsoclonus-myoclonus syndrome: an analysis of antigenic targets in neural tissues. J Pediatr. 1997;130:878-884 


\section{Immunologic and Clinical Responses to Rituximab in a Child With Opsoclonus-Myoclonus Syndrome}

Michael R. Pranzatelli, Elizabeth D. Tate, Anna L. Travelstead and Darryl Longee

Pediatrics 2005;115;115-119; originally published online Dec 15, 2004;

DOI: $10.1542 /$ peds.2004-0845

\section{This information is current as of January 5, 2005}

\begin{tabular}{|c|c|}
\hline $\begin{array}{l}\text { Updated Information } \\
\& \text { Services }\end{array}$ & $\begin{array}{l}\text { including high-resolution figures, can be found at: } \\
\text { http://www.pediatrics.org/cgi/content/full/115/1/e115 }\end{array}$ \\
\hline Supplementary Material & $\begin{array}{l}\text { Supplementary material can be found at: } \\
\text { http://www.pediatrics.org/cgi/content/full/peds.2004-0845/DC1 }\end{array}$ \\
\hline References & $\begin{array}{l}\text { This article cites } 25 \text { articles, } 3 \text { of which you can access for free } \\
\text { at: } \\
\text { http://www.pediatrics.org/cgi/content/full/115/1/e115\#BIBL }\end{array}$ \\
\hline Subspecialty Collections & $\begin{array}{l}\text { This article, along with others on similar topics, appears in the } \\
\text { following collection(s): } \\
\text { Therapeutics \& Toxicology } \\
\text { http://www.pediatrics.org/cgi/collection/therapeutics_and_toxico } \\
\text { logy }\end{array}$ \\
\hline Permissions \& Licensing & $\begin{array}{l}\text { Information about reproducing this article in parts (figures, } \\
\text { tables) or in its entirety can be found online at: } \\
\text { http://www.pediatrics.org/misc/Permissions.shtml }\end{array}$ \\
\hline Reprints & $\begin{array}{l}\text { Information about ordering reprints can be found online: } \\
\text { http://www.pediatrics.org/misc/reprints.shtml }\end{array}$ \\
\hline
\end{tabular}

